\title{
Low-cyclic Fatigue Test of Adhesive Bond Reinforced with Biodegradable Fabrics
}

Jan Zavrtálek, Miroslav Müller

Faculty of Engineering, Czech University of Life Sciences Prague. Czech Republic. E-mail: zavrtalek@tf.czu.cz; muller@tf.czu.cz

To improve mechanical properties of adhesive bonds and to reduce an amount of an adhesive spherical particles or fibres are used. Glass and carbon fibres are mostly used types of fibres, however, they are not environmental friendly. So biodegradable materials, namely jute, cotton and linen were used for experiments. The aim of the experiment is to clarify the fatigue behaviour of structural two-component epoxy adhesive applied to a constructional steel S235J0. The fabrics were composed of jute, cotton and linen in a plain weave and the weights in grams $140 \mathrm{~g} / \mathrm{m}^{2}$ for cotton, $261 \mathrm{~g} / \mathrm{m}^{2}$ for linen and $305 \mathrm{~g} / \mathrm{m}^{2}$ for jute were used. The specimens for quasi-static and lap shear strength tests were made in accordance with EN 1465:2009. It is obvious from the experiment results that it came to the improvement of the quasi-static loading at adhesive bonds reinforced with linen, the increase of static strength was about $28 \%$ compared with bonds without fabric layer.

Keywords: adhesive bond, biodegradable materials, scanning electron microscopy, low-cyclic fatigue

\section{Acknowledgement}

Supported by Internal grant agency of Faculty of Engineering, Czech University of Life Sciences Prague (Research on mechanical properties of multi-component polymer systems during their preparation, processing and application, 2016:31140/1312/3109).

\section{References}

[1] ABDEL WAHAB M. M. (2012). Fatigue in Adhesively Bonded Joints: A Review. In: ISRN Materials Science, Vol. 2012, pp. 25.

[2] BROUGHTON, W. R., MERA, R. D., HINOPOUlOS, G. (1999). Cyclic Fatigue Testing of Adhesive Joints, Test Method Assessment. Project PAJ3 - Combined Cyclic Loading and Hostile Environments 1996-1999, Report No 8, 34 pp. Centre for Materials Measurement \& Technology, National Physical Laboratory, Teddington.

[3] DAVIESA, P., SOHIERB, L., COGNARDC, J.Y., BORMAUDD, A. D., CHOQUESEUA, E., RINNERTE, E. (2009). Influence of adhesive bond line thickness on joint strength. In: International Journal of Adhesion and Adhesives, Vol. 29, No. 7, pp. 724-736.

[4] DUFLOU, J.R., DENG, Y., VAN ACKER, K., DEWULF, W. (2012). Do fiber-reinforced polymer composites provide environmentally benign alternatives? A life-cycle-assessment-based study. In: MRS Bulletin, Vol. 37, No. 4, pp. 374-382.

[5] HAFIZ, T. A., ABDEL WAHAB, M. M., CROCOMBE, A. D., SMITH, P. A. (2010). Mixed-mode fracture of adhesively bonded metallic joints under quasi-static loading. In: Engineering Fracture Mechanics, Vol. 77, No. 17, pp. 3434-3445.

[6] HOWARTH, J., MAREDDY, S.R., MATIVENGA, T. (2014). Energy intensity and environmental analysis of mechanical recycling of carbon fibre composite. In: Journal of Cleaner Production, Vol. 81, pp. 46-50.

[7] KELLY, G. (2006). Quasi-static strength and fatigue life of hybrid (bonded/bolted) composite single-lap joints. In: Composite Structures, Vol. 72, No. 1. pp. 119-129.

[8] MESSLER, R., W. (2004). Joining of materials and structures from pragmatic process to enabling technology. In: Joining of materials and structures, Burlington: Elsevier, $816 \mathrm{pp}$.

[9] MÜLLER, M., VALÁŠEK, P (2013). Assessment of bonding quality for several commercially available adhesives. In: Agronomy Research, Vol. 11, No. 1, pp. 155-162.

[10] MÜLLER, M. (2014). Research of Liquid Contaminants Influence on Adhesive Bond Strength Applied in Agricultural Machine Construction. In: Agronomy Research, Vol.11, pp. 147-154.

[11] MÜLLER, M., HERÁK, D., VALÁŠEK, P. (2013). Degradation limits of bonding technology depending on destinations Europe, Indonesia. In: Tehnicki Vjesnik-Technical Gazette, Vol. 20, No. 4, pp. 571-575.

[12] NAITO, K., ONTA, M., KOGA, Y. (2012). The Effect of Adhesive Thickness on Tensile and Shear Strength of Polyimide Adhesive, In: International Journal of Adhesion \& Adhesives, Vol. 36, pp. 77-85. 
[13] RUDAWSKA, A. (2012). Surface Free Energy and 7075 Aluminium Bonded Joint Strength Following Degreasing Only and Without Any Prior Treatment. In: Journal Adhesion Science and Technology, Vol. 26, pp. 1233 - 1247.

[14] SONG, Y.S., YOUNG, J.R., GUTOWSKI, T.G. (2009). Life cycle energy analysis of fiber-reinforced composites. In: Composites Part A: Applied Science and Manufacturing, Vol. 40, No. 8, pp. 1257-1265.

[15] ŠLEGER, V., MÜLLER, M. (2015). Quasi static tests of adhesive bonds of alloy AlCu4Mg, In: Manufacturing Technology, Vol. 15, No. 4, pp. 694-698.

[16] WITTEN, E. (2014). The European GRP Market, Composite Market Report 2014: Market Developments, Trends, Challenges and Opportunities, 44 pp.

[17] ZAVRTÁLEK, J., MÜLLER, M., ŠLEGER, V. (2016). Low-cyclic fatigue test of adhesive bond reinforced with glass fibre fabric. In: Agronomy Research, Vol. 14, pp. 1138-1146.

[18] MÜLLER, M. 2014. Setting of causes of adhesive bonds destruction by means of optical analysis. Manufacturing Technology, 14(3): 371-375.

[19] NOVÁK, M. (2012). Surfaces with high precision of roughness after grinding. In: Manufacturing technology. Vol. 12 , pp. $66-70$.

Copyright (C) 2016. Published by Manufacturing Technology. All rights reserved. 